\title{
Cultural adaptation and content validity of ISTAP Skin Tear Classification for Portuguese in Brazil
}

\section{Adaptação cultural e validade de conteúdo do ISTAP Skin Tear Classification para o português no Brasil}

\section{Adaptación cultural y validez de contenido del ISTAP Skin Tear Classification para portugués en Brasil}

\author{
Cinthia Viana Bandeira da Silva ${ }^{1,2}$, Ticiane Carolina Gonçalves Faustino Campanili2, \\ Kimberly LeBlanc ${ }^{3}$, Sharon Baranoski ${ }^{4}$, Vera Lúcia Conceição de Gouveia Santos ${ }^{5}$
}

\section{ORCID IDS}

Silva CVB (D) https://orcid.org/0000-0003-1430-1237 Campanili TCGF (D) https://orcid.org/0000-0003-4134-6035 LeBlanc K (D) https://orcid.org/0000-0001-5003-686X Santos VLCG (D) https://orcid.org/0000-0002-1288-5761

\section{HOW TO CITE}

Silva CVB; Campanili TCGF; LeBlanc K; Baranoski S; Santos VLCG. Cultural adaptation and content validity of ISTAP Skin Tear Classification for Portuguese in Brazil. ESTIMA, Braz. J. Enterostomal Ther., 16: e2618. doi: 10.30886/estima.v16.590.

\begin{abstract}
Objective: To translate and culturally adapt the International Skin Tear Advisory Panel (ISTAP) Skin Tear Classification into the Portuguese language in Brazil and test the content validity of the adapted version. Methods: The cultural adaption comprised three phases: translation, evaluation by committee of judges composed of five stomatherapists (confirming the instrument content validity) and back-translation. Results: Two Brazilian Portuguese versions of the instrument were obtained after translation and analyzed by the committee, disagreements arose over several health related terms. This generated low values of the content validity index. However, the content validity was confirmed after discussion of discrepancies between the authors and some members of the judges' committee, as well as with one of the authors of the original instrument, Dr. Kimberly LeBlanc, who also testified that validity when approving the back-translations of the adapted version to Brazilian Portuguese. Conclusion: The culturally adapted version of the ISTAP Skin Tear Classification is considered to have been obtained, with its content validity also attested. At that moment, the tests for inter and intraobserver reliability and concurrent validity are in the finalization phase, after which the instrument adapted and validated for Brazil will be made available.
\end{abstract}

DESCRIPTORS: Validation studies; Wounds and injuries; Methodological research in nursing; Advanced nursing practice.

\footnotetext{
1 Universidade de São Paulo - Faculdade de Medicina - Instituto do Coração do Hospital das Clínicas - São Paulo/SP - Brazil.

Universidade de São Paulo - Escola de Enfermagem - São Paulo/SP - Brazil.

${ }^{3}$ Western University - Scholl of Physical Therapy - Advanced Health Care Practice Program - Ontario - Canada.

${ }^{4}$ National Pressure Ulcer Advisory Panel - Washington, DC - USA.

5Universidade de São Paulo - Escola de Enfermagem - Departamento de Enfermagem Médico-Cirúrgica - São Paulo/SP - Brazil.

Corresponding author: Cinthia Viana Bandeira da Silva | Rua Sebastião Dias, 38 | ZIP Code: 02976-050 - São Paulo/SP - Brazil |

E-mail: bandeira.cinthia@gmail.com

Received: Mar. 072018 | Accepted: Jun. 282018
} 


\title{
RESUMO
}

Objetivo: Adaptar culturalmente o ISTAP Skin Tear Classification para a língua portuguesa no Brasil e testar a validade de conteúdo da versão adaptada. Métodos: Três fases compuseram a adaptação cultural: tradução, avaliação por comitê de juízes composto de cinco estomaterapeutas (gerando a validação de conteúdo do instrumento) e retrotradução. O projeto foi aprovado por comitê de ética em pesquisa. Resultados: Duas versões em português do instrumento foram obtidas após tradução e analisadas pelo comitê de juízes, ocorrendo discordâncias apenas em termos específicos utilizados na área, seguidas por sugestões para melhor adequação do vocabulário em saúde. Isso gerou valores baixos do índice de validade de conteúdo. No entanto, a validade de conteúdo foi confirmada após discussão das discrepâncias entre as autoras e alguns membros do comitê de juízes, bem como com uma das autoras do instrumento original, Dra. Kimberly LeBlanc, que também a atestou quando aprovou as retrotraduções dessa versão. Conclusão: Considera-se obtida a versão adaptada culturalmente do ISTAP Skin Tear Classification, com sua validade de conteúdo também atestada. Neste momento, os testes para confiabilidade inter e intraobservadores e validade concorrente estão em fase de finalização, após o que se disponibilizará o instrumento adaptado e validado para o Brasil.

DESCRITORES: Estudos de validação; Ferimentos e lesões; Pesquisa metodológica em enfermagem; Prática avançada de enfermagem.

\begin{abstract}
RESUMEN
Objetivo: Adaptar culturalmente el ISTAP Skin Tear Classification para la lengua portuguesa en Brasil y probar la validez de contenido de la versión adaptada. Métodos: Tres etapas constituyeron la adaptación cultural: traducción, evaluación por comité de jueces compuesto por cinco estomaterapeutas (generando la validación de contenido del instrumento) y traducción inversa. El proyecto fue aprobado por comité de ética en investigación. Resultados: Se obtuvieron dos versiones en portugués del instrumento después de ser traducidas y analizadas por el comité de jueces, habiendo discordancias solamente en términos específicos utilizados en el área, seguidas por sugerencias para mejor adecuación del vocabulario de salud. Eso generó valores bajos del índice de validez de contenido. Sin embargo, la validez de contenido fue confirmada después de discusión de las discrepancias entre las autoras y algunos miembros del comité de jueces, así como con una de las autoras del instrumento original, Dra. Kimberly LeBlanc, que también la certificó cuando aprobó las traducciones inversas de esa versión. Conclusión: Se considera obtenida la versión adaptada culturalmente del ISTAP Skin Tear Classification, también con comprobación de su validez de contenido. En este momento, las pruebas para confiabilidad inter e intraobservadores y validez coincidente están en etapa de finalización, después de lo que se hará disponible el instrumento adaptado y validado para Brasil.
\end{abstract}

DESCRIPTORES: Estudios de validación; Heridas y lesiones; Investigación metodológica en enfermería; Práctica avanzada de enfermería.

\section{INTRODUCTION}

Skin tears (ST) are traumatic wounds that occur primarily in the extremities and in the elderly, caused by shear, friction and/or brute force, resulting in the separation of the layers of skin. This separation may be of partial thickness when the dermis and epidermis separate, or of full thickness, when the dermis, epidermis and underlying structure are separated from each other ${ }^{1,2}$.

It is already known that some factors alter the healing process and these also present as risk factors for the appearance of ST, such as: extremes of age, especially the elderly older than 85 years; women and caucasians; impaired nutritional status; use of drugs such as immunosuppresives, antiinflammatory agents and anticoagulants, the last often causing the appearance of ecchymoses; smoking; loss of sensation; dependency for activities of daily living; impaired mobility; and current disease state ${ }^{1,3}$.

There is much debate surrounding the nomenclature and methods for describing and documenting STs. Payne and Martin ${ }^{4,5}$ published seminal work in 1990 when they developed the Payne-Martin Classification System for Skin Tears. Although no measured properties tested, the system was and still is widely used ${ }^{6}$. Since that time two distinct international groups have proposed new classification systems, both based on Payne-Martin's first initiative: The Skin Tear Audit Research (STAR) Skin Tear Classification System² was developed Australia in 2007, and International Skin Tear Advisory Panel (ISTAP) ${ }^{1}$ developed the ISTAP Skin Tear Classification System in 2011. 
In Brazil, the process of cultural adaptation and validation of the STAR Skin Tear Classification System ${ }^{7}$ was recently published, introducing the new nomenclature - skin tear replacing the previous one, traumatic laceration or wound, considered more generic. Developed by a group of Australian nurses specialized in wound care and coordinated by Prof. Dr. Kerlyn Carville, STAR is comprised of treatment guide, classification system and glossary. The treatment guide presents six topics for wound and surrounding skin care, and the classification system evaluates the presence/absence of the skin flap and its viability in five photos, each related to its respective categorical description. The glossary, in turn, provides definitions of the ST and the technical related vocabullary $^{2}$.

ISTAP, originally coordinated by Dr. Kimberly LeBlanc and Sharon Baranoski, is also responsible for developing consensus on diagnosis, treatment and prevention of these acute traumatic injuries. The decision for its development was based on a survey conducted in 16 countries, with 1.127 health professionals, of whom $69.6 \%$ reported difficulties in establishing the evaluation and documentation of $\mathrm{ST}^{1}$. The consensus was first developed by a committee of 13 wound specialists from the United States, Canada, the United Kingdom and Australia. After the consensus document was obtained, it was finally reviewed by an advisory committee composed of 68 international external collaborators, also wound care specialists. In the end, the members of both committees finalized the consensus consisting of 12 statements on ST evaluation, prediction, prevention and treatment. The consensus also included a new simpler classification system, ISTAP Skin Tear Classification, that could be quickly incorporated into clinical practice. Similar to the other systems previously presented, ISTAP Skin Tear Classification consists of an association of photos, in this case, three types of injuries characterized as linear rupture with totally present flap, partial loss of the flap and total loss of the flap (Figure 1$)^{1}$.

The internal validity of ISTAP Skin Tear Classification was established through simultaneous evaluation of photos by specialists. Thus, an original bank containing 74 high quality photos provided by the remaining 12 committee members who worked out the consensus was evaluated by Dr. LeBlanc after the consent of the authors of the photos. Among these, LeBlanc selected 30 photos representing the three types of STs. These photos were sent to committee members to test the instrument's internal validity. The members were advised to classify the photos into three groups, according to the similarity of the characteristics, without reference to the proposed classification system $^{8}$.

Stability was tested two months later, repeating the above procedure with satisfactory agreement (Cohen $\mathrm{k}=0.877$ ). For external validity, the study used a sample of 190 individuals (nurses and professionals from other health areas) who went through the same process of grouping the photos, again without referring to the classification system,

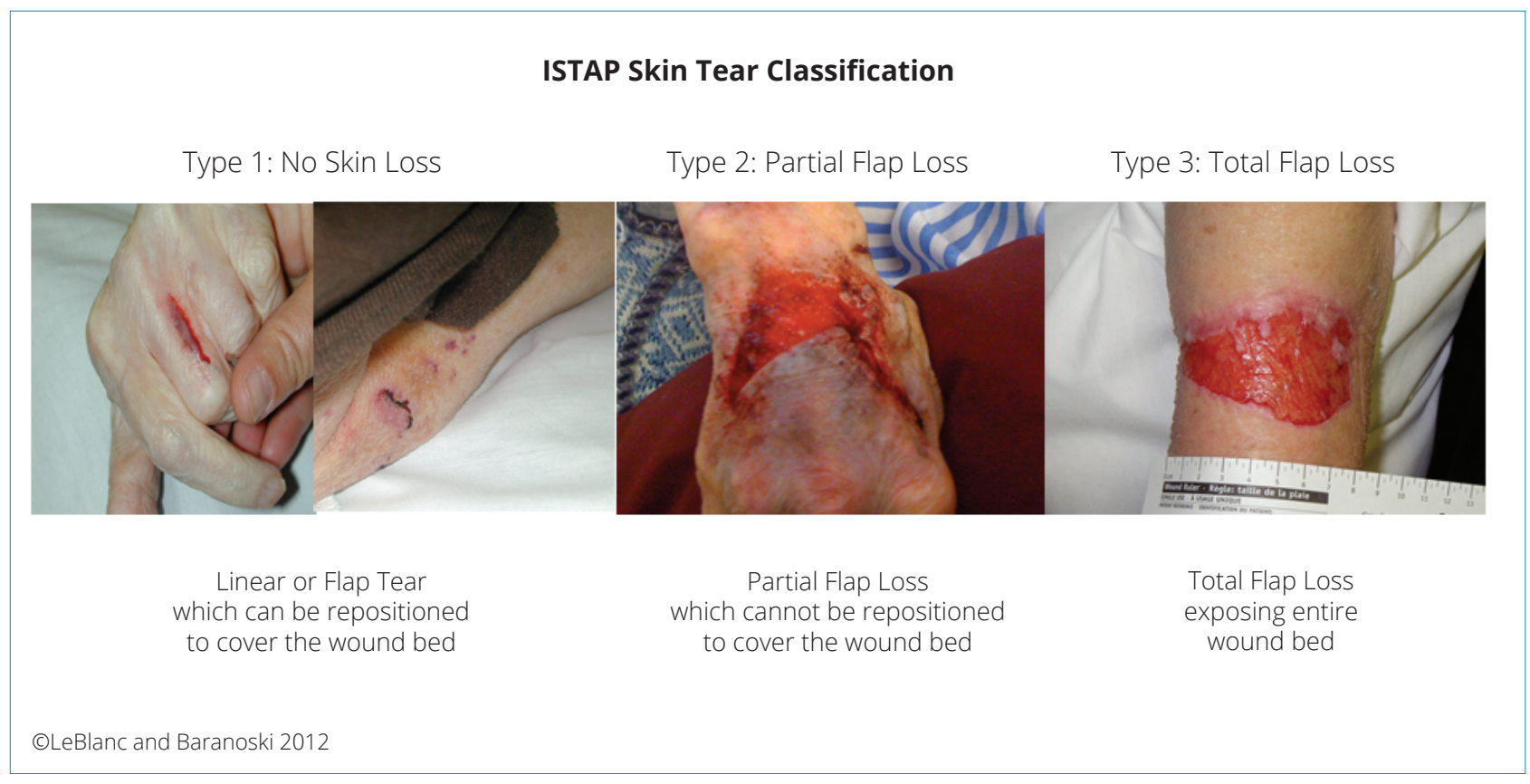

Figure 1. ISTAP Skin Tear Classification8 (reproduction authorized by the main author). 
that is, only by similarity of characteristics, obtaining moderate level of agreement $(\text { Fleiss } \mathrm{k}=0.545)^{8}$.

ST are injuries that are poorly studied and, therefore, underreported, often being misdiagnosed as pressure injuries. Brazil is one of the few Latin American countries with published studies about ST, and yet these injuries are poorly known in clinical practice. The cultural adaptation and validation of a second international simple and accessible classification system, such as ISTAP Skin Tear Classification, will allow a common systematized language, facilitating communication between health professionals, the most appropriate planning of the assistance to be provided, and the comparison of the results of our publications with those achieved by international authors. The objective of this study is to present only the cultural adaptation stage of the ISTAP Skin Tear Classification, as well as the content validity analysis of the adapted version, as one of the components of cultural adaptation process of measurement instruments.

\section{METHODS}

This is a methodological study with a quantitative approach on the cultural adaptation of the ISTAP Skin Tear Classification based on the proposal of Beaton et al. ${ }^{9}$.

The invitation and authorization for ISTAP Skin Tear Classification cultural adaptation and validation for Brazilians was made by Dr. Kimberly LeBlanc, coordinator of the international ISTAP committee, to Prof. Dr. Vera Lucia C. G. Santos. The Research Ethics Committee of Nursing School of Sao Paulo University (EEUSP) approved the project (66513517.7.0000.5392/2017/ CEPEEUSP) as well as the Heart Institute (InCor) of the Clinicals Hospital of Medical School of the University of São Paulo, where the data collection was performed to evaluate the measurement properties of the adapted version of the instrument. Participating nurses and patients were included in the study sample only after consent and anonymity were guaranteed. Although the present study relates only to the stage of cultural adaptation of ISTAP Skin Tear Classification to Portuguese in Brazil, the project was approved as a whole in the instances described previously. The study was developed as a conclusion work of the Nursing Residency Program in Cardiopneumology of High Complexity of EEUSP-InCor.
The adaptation process included three stages: translation, judging by committee of judges (in which content validity was also tested) and back-translation.

First, the ISTAP Skin Tear Classification was translated by two Brazilian translators, fluent in English: a lay person in the health area, without knowledge of the research project, and a nurse aware of the study's aims. The translations were named, respectively, T1 and T2. Both classified each item of the instrument as to the degree of difficulty in the translation process (0 to 10 ).

The two translations were then analyzed by a committee of judges composed of five Brazilian specialized nurses in stomatherapy, fluent in English, experts in the treatment of patients with wounds and with knowledge of the concepts of the instrument. The judges' committee is a fundamental part of achieving the cultural equivalence of the translated instrument and its evaluation is aimed at analyzing the semantic (grammatical correspondence and meaning of words), idiomatic (substitution of specific colloquial expressions, rarely translatable, by equivalent terms), cultural (coherence between the terms used and the culture of the population to which the instrument is intended) and conceptual (if the translated terms reflect the same original concepts) equivalences between the translated and original versions ${ }^{9}$. Each judge proceeded to the analysis using Likert scale (1 to 4), respectively: totally disagree, disagree, agree and totally agree. In addition to this analysis, the members of the committee were asked to suggest changes to suit and improve the wording of the items in order to better adjust the translations made to the health area. The agreement between the judges' answers was analyzed through the content validity index (CVI) obtained by the proportion of items that received scores 3 or 4 by the judges ${ }^{10-13}$ :

Content validity indicates to what extent the instrument has an appropriate sample of items to measure the particular construct and adequately cover its domain. It is increasingly common to use a group of independent experts to evaluate the content validity of new instruments. The CVI indicates the extent to which the opinions of the experts are congruent, by measuring the proportion or percentage of judges who agree on the aspects and items of the instrument. Besides analyzing the items, it allows analyzing the instrument as a whole. The excellence level of the content validity is achieved with an CVI of $0.90^{10-13}$.

Based on the judges' answers, a single version was established by the researchers who discussed the discrepancies 
with some of the committee members and with one of the authors of the original instrument, Dr. LeBlanc. The resulting version was then forwarded to back-translation, also performed by two translators, both lay in health care and who had English as their native language. Both backtranslated versions were forwarded to Dr LeBlanc in order to confirm the equivalence between the original and the Brazilian adapted version. The data were grouped into Excel spreadsheets and analyzed through the Statistical Package for Social Sciences Program (SPSS) version 22.0.

\section{RESULTS}

\section{Translation}

Two Brazilian Portuguese versions of the instrument were obtained (T1 and T2). For the lay translator in the health area (T1), both the title and the definition of the first type of injury presented higher degrees of difficulty to be translated (classified as 8), justified by lack of knowledge in the health area. Already the translator who knew the objective of the study (T2) mentioned difficulty only when translating the term tear. The two versions still showed slight differences as to the translations of the terms flap and wound bed: flap was translated as $a b a$ and borda and wound bed as leito and base da ferida.

\section{Committee of judges' analyses}

The mean CVI was 0.66, when calculated according to the mean proportions (Table 1 ).

The translations with higher values of CVI (0.8 and 1$)$ are related to the instrument title (ISTAP Skin Tear Classification) and type 1 (without skin loss). All other translations obtained suggestions for the adequacy of the translated terms.

The word flap generated significant disagreement between judges and translators on all items in which they appeared, reducing CVI values. The incorrect translation of this term led the judges to suggest the use of the terminology retalho cutâneo instead of $a b a$ or borda, indicated in the translations.

Another important item of discussion was the definition of ST type 1 (CVI: 0.4), which includes two ST subtypes (linear rupture and cutaneous flap - both without loss of cutaneous tissue or skin) and, therefore,
Table 1. Content validity index (CVI) of translated versions of the instrument to Brazilian Portuguese. São Paulo. SP. Brazil. 2017.

\begin{tabular}{|c|c|c|c|}
\hline \multirow{2}{*}{ ISTAP Classification - item } & \multicolumn{2}{|c|}{ CVI } & \multirow{2}{*}{$\begin{array}{c}\text { Total } \\
\text { mean CVI }\end{array}$} \\
\hline & $\mathrm{T} 1$ * & $\mathrm{T} 2 *$ & \\
\hline Instrument title & 0.2 & 0.8 & \\
\hline Title of ST type 1 & 1 & 1 & \\
\hline ST type 1 definition & 0.2 & 0.4 & \\
\hline Title of ST type 2 & 0 & 0.6 & 0.66 \\
\hline ST type 2 definition & 0.6 & 0.2 & \\
\hline Title of ST type 3 & 0.4 & 0.4 & \\
\hline ST type 3 definition & 0.6 & 0.4 & \\
\hline
\end{tabular}

leads to two different forms of "covering" the injury (linear or flap tear that can be repositioned to cover the wound bed). In this case, the main researchers chose to discuss the content of the definition with some of the committee members, with the non lay translator, as well as with Dr. LeBlanc. The discussions resulted in a definition that included two forms of coverage from the subtype (linear or flap): reaproximação de bordas or reposicionamento do retalho, respectively.

To obtain the T3 version, at the end of this phase, the judges' suggestions were considered and it was established that the term lesão would be standardized throughout the instrument, rather than the word ferida. The suggestions of the judges were similar in all aspects of the instrument, the differences being characterized only with regard to synonymy, verb tenses and prepositions, that is, grammatical differences.

\section{Back-translation}

There were no difficulties reported by translators at this stage. There were small differences between the back-translated and the original versions, but without any changes in meanings or content. To finalize the version adapted by the researchers, only the definition of ST type 1 generated a new discussion with the original author. Dr. LeBlanc commented on the difference in content that, in the adapted version, included a more detailed explanation on the form of ST type 1 coverage, in both cases: linear injury and cutaneous flap. Considering that only the edge approach is possible to "cover" the injury in case of linear rupture and that the repositioning of the flap is only possible when it exists, the researchers considered it important to detail such an explanation 
whose concept seems clear in the English language, but loses its veracity in the Brazilian Portuguese language. This justification was accepted by the original author and remained in the final adapted version. With the approval of the author, the adapted version of the ISTAP Skin Tear Classification was finalized as Classificação ISTAP para Lesões por Friç̧ão.

\section{DISCUSSION}

This article consists of the report of the first stage of a larger study, developed during the High Complexity Cardiopneumology Nursing Residency Program of EEUSP-InCor, aimed at cultural adaptation and validation of the ISTAP Skin Tear Classification, according to the Beaton et al. methodology ${ }^{9}$, classical in the academic environment.

Since the instrument translation phase, some problems have been encountered with some terms that have already presented difficulties in a previous study of cultural adaptation and validation of STAR Skin Tear Classification System ${ }^{7}$, also developed by one of the researchers of the present study. The term skin tear or directly the word tear required in-depth study on the laws of mechanics to better understand the etiology of the injury and establishment of the term lesão por friçça $o^{8}$ maintained herein.

As for the evaluation of translations by committee of judges, very low CVI levels were obtained (mean CVI: 0.66), much below the cutoff value (0.9) ${ }^{10,13}$, which could be interpreted as absence of content validity, to immediate criticism. However, these results originate from the inadequate translation of the term flap that appears in the definitions of the three ST types. The final version was established after extensive discussion among the researchers, some members of the judges' committee and the original author, as the literature indicates in case of low $\mathrm{CVI}^{10,11}$. The standardization of the terms retalho cutâneo and leito da lesão, respectively, for flap and wound bed, was due to its current use in the literature specialized in dermatology, plastic surgery and stomatherapy. As evidenced by Neto ${ }^{14}$, the cutaneous flap is composed of a mobilized tissue attached to its vascular pedicle to maintain its irrigation. Irrigation of the skin occurs through superficial branches originating from the superficial fascia. Besides these, and as described in the Results section, the definition of type 1 - without skin loss - generated a great discussion, since it is the only type of injury that covers two subtypes. In order to avoid its inaccuracy, the discussions resulted in the detailing of its contents, approved by all, including by the original author, who could observe that in the back-translations. Thus, the content validity of the final Brazilian Portuguese version of the ISTAP Skin Tear Classification was confirmed.

Until now, only one group in Denmark has performed the translation and validation of the ISTAP Skin Tear Classification System, following the same methodology used in the original study. The English to Danish translation was performed by two groups with four nurses specialized in dermatology, being later analyzed and mixed for final version by two of the authors of the adaptation. Then, this version was sent to back-translation, performed by two translators, a lay in the area and a nurse with knowledge of the study's objective. The adapted version was then submitted to a validation process similar to the original one. The 30 original photos belonging to ISTAP were applied to 270 professionals, nurses $(\mathrm{n}=241)$ and physicians $(n=29)$. The level of agreement presented was moderate for both groups (Fleiss Kappa $=0.464$ and 0.443, respectively), a result that resembles those obtained in the original study ${ }^{15}$. Although the other measuring properties of the instrument have not yet been analyzed in the Brazilian Portuguese adapted version, comparisons with the original and the Danish studies become difficult as methods used in both are different from those adopted here.

\section{Recommendations and limitations}

The ISTAP has been working with wound care specialists in all continents aiming to disseminate its classification system and other prevention and treatment protocols and to achieve a standardized language regarding ST, which would facilitate the recovery of the problem and comparison of the results obtained around the world. In addition, the Panel is adjusting and reviewing the ST nomenclature. Performing cultural adaptation and validation of the classification system are the best way to standardize the language and spread that across countries. Except for Denmark, the first country to adapt and validate the ISTAP Classification System, only Sweden, Czech Republic, Quebec (French Canadian), Brazil and Chile are in the process of adaptation and validation of the instrument. In parallel, the Panel attempts 


\section{CONCLUSION}

to introduce the term "skin tear" into the International Statistical Classification of Diseases and Related Health Problems (ICD) and Medical Subject Headings (MeSH).

A limitation of this manusrcipt is that as the result of time constraints and workloads, the study cannot be published in its entirity at this time. This manuscript represents the translation and cultural adaptation of the ISTAP ST Classification system. Phase two which is aimed at exploring the validity and reliability of the system in clincial practice. In order to provide an adapted, reliable and valid instrument for use in the country, some measurement properties will be analyzed after the end of data collection (inter and intraobserver reliability and concurrent criterion validity).
The ISTAP Skin Tear Classification has been adapted for the Brazilian Portuguese language, confirming also its content validity.

\section{AUTHOR'S CONTRIBUTION}

Conceptualization, Silva CVB; Campanili TCGF; LeBlanc K; Baranoski S; Santos VLCG.; Methodology, Silva CVB; LeBlanc K; Santos VLCG; Investigation, Silva CVB; Campanili TCGF; Writing - First version, Silva CVB; Santos VLCG; Writing - Review \& Edition, Silva CVB; LeBlanc K; Santos VLCG.

\section{REFERENCES}

1. LeBlanc K, Baranoski S. Skin tears: state of the science: consensus statements for the prevention, prediction, assessment, and treatment of skin tears@. Adv Skin Wound Care. 2011;24(9):2 15. doi: https://doi.org/10.1097/01.ASW.0000405316.99011.95.

2. Carville $K$, Lewin G, Newall N, Haslehurst $P$, Michael $\mathrm{R}$, Santamaria $\mathrm{N}$, et al. STAR: a consensus for skin tear classification. Prim Intent Aust J Wound Manag. 2007;15(1):18-27.

3. Amaral AF dos S, Strazzieri-Pulido CS, Santos VLC de G. Prevalence of skin tears among hospitalized patients with cancer. Rev da Esc Enferm. 2012;46(Special):44-50. doi: https://doi.org/10.1590/S0080-62342012000700007.

4. Payne RL, Martin ML. The epidemiology and management of skin tears in older adults. Ostomy Wound Manage. 1990; 26:26-37.

5. Payne RL, Martin ML. Defining and classifying skin tears: need for a common language. Ostomy Wound Manage. 1993;39(5):16-20,22-4,26.

6. Strazzieri-Pulido, KC. Adaptação cultural e validação do instrumento "STAR Skin Tear Classification System" para a língua portuguesa no Brasil [thesis]. São Paulo (SP): Universidade de São Paulo, Escola de Enfermagem, Mestrado em Enfermagem na Saúde do Adulto; 2010. doi: https://doi.org/10.11606/D.7.2010.tde-23122010-103305.

7. Strazzieri-Pulido KC, Santos VLC de G, Carville K. Cultural adaptation, content validity and inter-rater reliability of the "STAR Skin Tear Classification System". Rev Lat Am Enfermagem. 2015;23(1):155-61. doi: https://doi.org/10.1590 /2F0104-1169.3523.2537.

8. LeBlanc K, Baranoski S, Holloway S, Langemo D. Validation of a new classification system for skin tears. Adv Ski Wound Care. 2013;26(6):263-5. doi: https://doi.org/10.1097/01. ASW.0000430393.04763.c7.
9. Beaton D, Bombardier C, Guillemin F, Ferraz MB. Recommendations for the cross-cultural adaptation of the DASH \& QuickDASH outcome measures [Internet]. Rosemont: American Academy of Orthopaedic Surgeons and Institute for Work \& Health; 2007 [Accessed 2017 Mar 19]. Available at: http://www.dash.iwh.on.ca/sites/dash/files/ downloads/cross_cultural_adaptation_2007.pdf.

10. Alexandre N, Gallasch C. A confiabilidade no desenvolvimento e avaliação de instrumentos de medida na área da saúde. RevEletrônica.2013;15(3):802-9.doi:https://doi.org/10.5216/ ree.v15i3.20776.

11. Polit DF, Beck CT. The content validity index. Are you sure you know what's being reported? Critique and recommendations. Res Nurs Heal. 2006;29(5):489-97. doi: https://doi.org/10.1002/nur.20147.

12. Mcdowell I. Measuring Health: a guide to rating scales and questionnaires. Statistics in medicine. Oxford: Oxford University; 2006. doi: https://doi.org/10.1093/acprof:o so/9780195165678.001.000.

13. Souza AC de, Alexandre NMC, Guirardello E de B, Souza AC de, Alexandre NMC, Guirardello E de B. Propriedades psicométricas na avaliação de instrumentos: avaliação da confiabilidade e da validade. Epidemiol e Serviços Saúde. 2017;26(3):649-59. doi: https://doi.org/10.5123/S167949742017000300022

14. Neto NT, Chi A, Ferreira MC. Tratamento cirúrgico das feridas complexas. Rev Med. 2010;89(3/4):147-52.

15. Skiveren J, Bermark S, LeBlanc K, Baranoski S. Danish translation and validation of the International Skin Tear Advisory Panel Skin Tear Classification System. J Wound Care. 2015;24(8):388-92. doi: https://doi.org/10.12968/ jowc.2015.24.8.388 